\title{
A Systematic Review: Factors Related to Happiness and Quality of Life in the Elderly Depression
}

\author{
Thika Marliana $^{1,2 *} \mathbb{D}$, Budi Keliat ${ }^{3} \mathbb{D}$, Novy Helena Catharina Daulima ${ }^{3} \mathbb{D}$, Tri Budi W. Rahardjo ${ }^{2}$ \\ ${ }^{1}$ Doctoral Program, Faculty of Nursing, Universitas Indonesia, Depok, Indonesia; ${ }^{2}$ Center of Aging and Family Studies, \\ Universitas Respati Indonesia, Jakarta, Indonesia; ${ }^{3}$ Department of Mental Health Nursing, Faculty of Nursing, Universitas \\ Indonesia, Depok, Indonesia
}

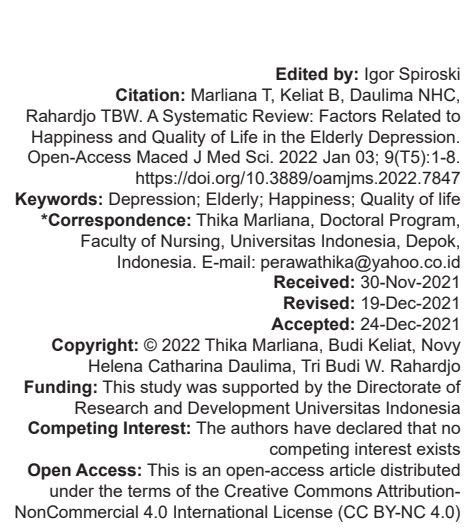

\section{Introduction}

Population aging, the shift toward an increased proportion of the elderly in the population, is a global phenomenon resulting from rapid declines in fertility rates coupled with reductions in mortality and increased longevity. Indonesia's elderly population is growing at an unprecedented rate from 1990 through 2020 and experiencing an increase in life expectancy from 66.7 years to 70.5 years. As a result, the number of Indonesian elderly will increase to 28.8 million (11\% of the total population) in 2020 and 80 million (28.68\%) in 2050 [1]. The longer a person's life, the more the person is prone to experience physical, mental, spiritual, economic, and social problems.

Many people think that mental health problems are just a normal consequence of aging. However, difficulties with mood, thinking, and behavior are not an inevitable part of aging. Depression is a common mental disorder with a 12-month prevalence of $5.3 \%$ and a lifetime prevalence of $13.2 \%$ [2]. The elderly who died of suicide and had a history of suicidal behavior were more likely to suffer from depression [3]. Depression in the elderly has become a significant public health issue. However, it is frequently underdiagnosed and undertreated. Early recognition and treatment of depression in the elderly will lead to improving daily functions and mortality.

The Basic Health Research data released in 2018 showed that the prevalence of depression in the Indonesian population is 6.1\% [4]. Depression is the most common mental illness in patients aged over 60 years and is an example of the most common disease with symptoms that are not specific/not typical of the elderly. Changes in the central nervous system, such as increased monoamine oxidase activity and reduced concentrations of neurotransmitters (especially catecholaminergic neurotransmitters), can play a role in depression in the elderly. In addition, the comorbid conditions with various chronic and polypharmacy diseases increase the incidence of depression in the elderly [13]. Geriatric patients suffering from depression also often have a comorbid vascular disease with lesions in the brain's basal ganglia and prefrontal regions. These patients often show a decline in motor function [10], lack of judgment ability [11], and disruption of the executive function [12]. 
Moreover, it is related to considerable reductions in health-related quality of life (QoL). Impairment in QoL impacted in mental, physical, and social functioning and negatively affects a various aspect of the individual's daily life. QoL is a surrogate indicator for general wellbeing. The depressive symptom was also closely related to QoL. Depressive symptoms in the elderly in patients with chronic illness were associated with the decline in self-rated QoL. Through this paper, the author will provide a systematic review of the factors related to happiness and quality of life in elderly people who experience depression. This systematic review aims to identify essential comprehensive factors contributing to increasing happiness and QoL in the elderly depression.

\section{Methods}

This study used systematic review approaches. It is a reference standard for synthesizing evidence in health care because of its methodological rigor. Using this review method, the researcher attempts to collate all relevant evidence that fits pre-specified eligibility criteria to answer a specific research question. We strictly obeyed the protocol as an essential component of the systematic review process. In addition, this research's consistency with the researcher promoter as a review team ensures accountability, research integrity, and transparency of the eventually completed review.

A protocol may also reduce arbitrariness in decision-making when extracting and using data from primary research since planning provides an opportunity for the review team to anticipate potential problems. The Preferred Reporting Items for Systematic Reviews and Meta-Analyses (PRISMA-P) checklist is intended primarily for the preparation of protocols of systematic reviews. This research has obtained ethical clearance from the Faculty of Nursing, the University of Indonesia, with the number 37/UN2. F12.D1.2.1/ETIK 2019.

\section{Inclusion and exclusion criteria}

\section{Search strategies and information resources}

To ensure that our review was relevant to this study's current practice and aims, we included articles indexed in the scientific databases EBSCO, ProQuest, Science Direct, Willey Online Library, Scopus, and SINTA. Articles search performed to complete this systematic review used keywords on a database tailored to research topics and titles and used Boolean operators' standard and equivalent words obtained from Medical Subject Headings. Keywords used include "Elderly" AND "Depression" AND "Happiness"
OR "Quality of Life."

\section{Quality assessment}

All evaluations, descriptive a comprehensive reviews of essential factors influencing the happiness and QoL in the elderly depression, were screened independently by two authors. Initially, we screened the title and abstract of all identified studies for eligibility the decisions guided by an eligibility instrument. Then, we used preferred reporting items for the format of the systematic review [5]. Finally, to assess the present risk of bias of the studies, we identified used the Cochrane risk of bias assessment tool from "Assessing risk of bias in included studies" by J.P.T. Higgins, D.G Altman, and J.A.C Sterne, in Cochrane Handbook for Systematic Reviews of intervention (version 5.1.0), shown in Table 3.

\section{Data extraction}

All screening identified studies for eligibility based on title and abstracts using an eligibility assessment tool to determine if the study discussed the essential factors influencing the happiness and QoL in the elderly depression. As a result, there were 102 full-text articles exclude with the reasons: Not depression in the elderly (16), search strategy not published (17), relevant studies did not meet inclusion criteria (53), no statistical pooling (1), not relevant (13), and $<10$ patient (2). The process of protocol systematic review in this research can show in Figure 1 (PRISMA flowchart details), as shown in Table 1 and Table 2 which is a summary of the inclusion and exclusion criteria as well as the publications used in this study.

\section{Results}

\section{Search results}

Based on the flowchart for the article search strategy method or PRISMAdiagram, at the identification stage, there were 2628 articles. Records, after duplicates were removed, were 993 articles. Full-text articles assessed for eligibility were 127 articles. Finally, the selected studies were 25 articles, categorized into type of study design, level of evidence, sample size, type of intervention, and outcome measure. Level of evidence used evidence-based medicine from British Medical Journal, divided into five levels (Level 1: Systematic review, meta-analyses, randomized control trials (RCT); Level II: Two groups, non-random; Level III: One group, non-random; Level IV: Descriptive studies that include analysis of outcomes; and Level V: Case report and expert opinion that include a narrative literature review and consensus statement). 


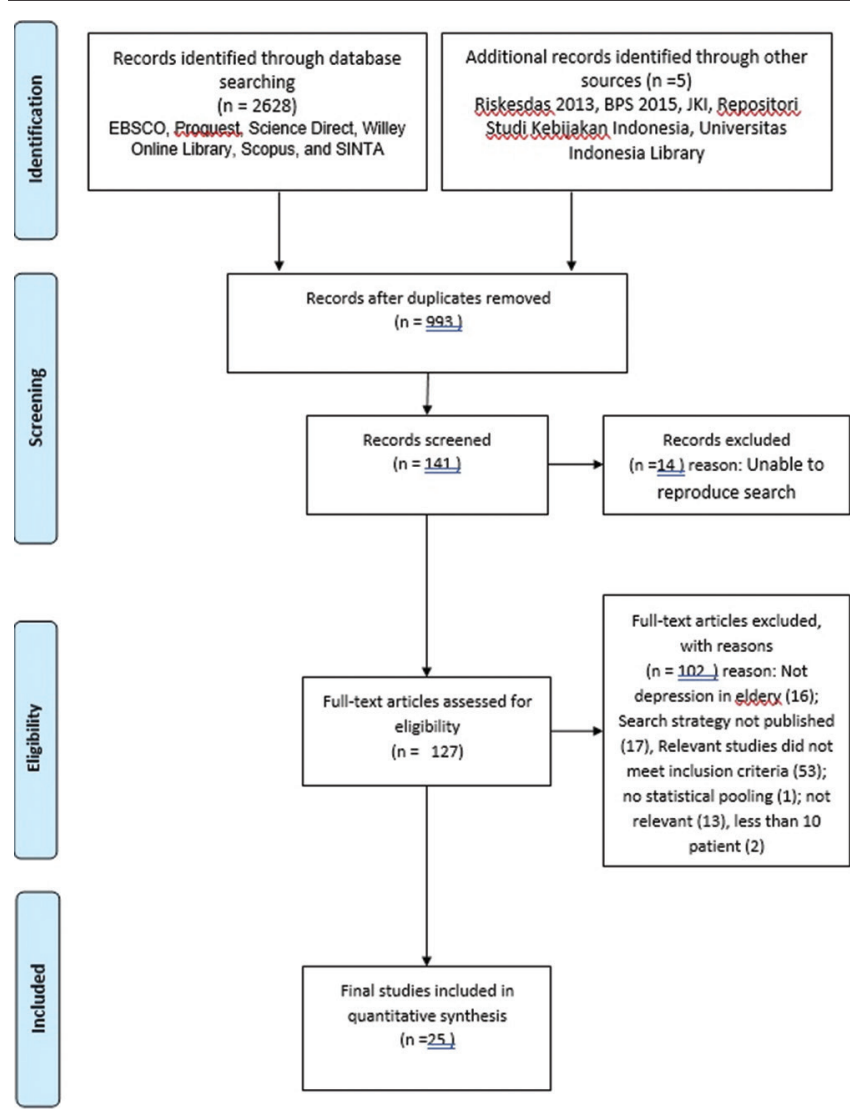

Figure 1: Preferred Reporting Items for Systematic Reviews and Meta-Analyses flowchart details of factors related to happiness and quality of life in the elderly depression

Study characteristics of 25 included studies, seven were RCT design, seven were cohort design, four were one group with before-after and pre-posttest design, four were case-control, and three with quasi-experimental design related to identifying the essential factors influencing the happiness and QoL in depression elderly. The majority of studies that identify depressive symptoms used geriatric depression scale (GDS). The depressive symptom is associated with reduced QOL; GDS scores above 9/30 or $5 / 15$ best predict poor perceived health-related QOL [6]. Therefore, these cutoff scores could identify subjects in whom treatment is more likely to improve QOL and yield a favorable cost-effectiveness ratio. Thus, GDS proved to be a reliable and valid questionnaire for evaluating depression [7]. In the present study, GDS showed good psychometric properties.

Table 1: Inclusion and exclusion criteria

\begin{tabular}{lll}
\hline No. & Inclusion criteria & Exclusion criteria \\
\hline 1. & Population in study focuses on the & Population in study not adolescence and \\
& elderly depression & adult age \\
2. & Quantitative design & Qualitative study \\
3. & Level of evidence three above & Lowest (IV) level of evidence \\
4. & Research articles published in the & Research articles published before 2015 and \\
& period 2015-2019 and full text & not open access \\
5. & Articles in English & Other translation language other than English \\
\hline
\end{tabular}

\section{Characteristics of respondents}

The total number of research respondents from 25 research articles reviewed was 17.439 elderly depression. Respondent came from nine countries
(China, Vietnam, Italia, Taiwan, Korea, Japan, Turkey, the USA, and Germany). The highest number of respondents was found in Germany in cohort design with 2364 elderly that examine the impact of social engagement in elderly depression. The average age of respondents is 60-85 years old, both male and female.

\section{Factors related to happiness and QoL}

Essential factors influencing the QoL in the elderly depression are lack of developmental tasks stimulation, religious belief, satisfaction regarding the QoL, suffering from more chronic disease, experiencing an adverse event, and lack of ability to take self-care. However, the most influential factor in increasing happiness in the elderly is a feeling of satisfaction with life achievement.

Terminology happiness is preferred over the term well-being and QoL. Happiness is a concept that refers to positive emotions [11] felt by individuals (such as when using ecstasy) as well as positive activities that have no emotional component at all (such as the individual's overall involvement in activities he likes), it is related to the QoL. Happiness is a subjective concept because each individual has different benchmarks of happiness. Each individual also has different factors that can bring happiness to him. The primary consideration refers to that happiness includes the phenomena of life that is so complex that the various determinants are correlated covered by three dimensions of life, namely: (1) Dimensions Satisfaction Life (Life Satisfaction), (2) Dimensions Feelings (Affect), and (3) Dimensions of the Meaning of Life (Eudaimonia). The essential factors considering predisposing depression in the elderly are traumatic experience (personal life experience, inner child of elderly, and social experience), life change becomes older adulthood, satisfaction with life (related to the psychosocial developmental task), history of chronic disease and self-care inability, religious belief, as well as one's religion or level of religiosity.

Traumatic experiences in the elderly can affect psychosocial growth and development at the individual development stage. Therefore, exploring the elderly's perception of the journey of life becomes something important. Inadequate understanding and appreciation of past events and overemphasis on bad events are the two main things that lead to calm, relief, and contentment. Positive emotions in the past can be enhanced by cultivating gratitude and forgiveness. Gratitude can increase appreciation and understanding of past good events. Forgiveness is the act of leaving the memory intact but by removing or changing the pain. Forgiveness can reduce the bitterness of bad events and can even turn bad memories into good ones.

Life change becomes older adulthood should become wiser, they developing integrity. When the previous development experiences positive things, he will achieve ego integrity and, facing life this time, 
Table 2: Final studies included

\begin{tabular}{|c|c|c|c|c|c|c|c|}
\hline No. & Author, Year & $\begin{array}{l}\text { Level of } \\
\text { evidence }\end{array}$ & Study design & Sample size & Intervention & Outcome measures & Results \\
\hline 1 & $\begin{array}{l}\text { Lin et al. } \\
\text { (2014) }\end{array}$ & II & Case-control & $\begin{array}{l}471 \text { elderly } \\
\text { inpatient }\end{array}$ & Comprehensive Geriatric Assessment & Degree of QOL and functionally & $\begin{array}{l}\text { Worst } \mathrm{QOL} \text { and } \mathrm{ADL} \text { in discharge } \\
\text { were found among the depressed } \\
\text { Factors affecting: Depressive } \\
\text { symptom, female gender, duration of } \\
\text { hospital stay, rehabilitation }\end{array}$ \\
\hline 2 & $\begin{array}{l}\text { Holland et al. } \\
\text { (2015) }\end{array}$ & III & $\begin{array}{l}\text { One group with } \\
\text { pre-post test }\end{array}$ & $\begin{array}{l}51 \text { geriatric } \\
\text { depression }\end{array}$ & Measuring depression & Promote meaning & $\begin{array}{l}\text { Those with more education showed } \\
\text { improvement in their ability to regain } \\
\text { positive values, worldviews, and } \\
\text { purpose in life }\end{array}$ \\
\hline 3 & $\begin{array}{l}\text { Ho et al. } \\
(2017)\end{array}$ & II & Cohort & $\begin{array}{l}2000 \text { males, } 2000 \\
\text { females aged } 65 \\
\text { years and above }\end{array}$ & Assessment of geriatric depression & Spatial variability & $\begin{array}{l}\text { A significant difference in geriatric } \\
\text { depression risk between unadjusted } \\
\text { and adjusted models, suggesting } \\
\text { the importance of including } \\
\text { environmental factors in estimating } \\
\text { geriatric depression risk }\end{array}$ \\
\hline 4 & $\begin{array}{l}\text { Feng et al. } \\
(2014)\end{array}$ & II & Cohort & $\begin{array}{l}1329 \text { elderly above } \\
50\end{array}$ & Measurement and evaluation & $\begin{array}{l}\text { Assessment of geriatric } \\
\text { depression }\end{array}$ & $\begin{array}{l}\text { Religious belief, satisfaction regarding } \\
\text { the quality of life, suffering from more } \\
\text { chronic disease, experiencing a } \\
\text { negative event, lack of ability to take } \\
\text { self-care was associated with having } \\
\text { geriatric depression }\end{array}$ \\
\hline 5 & $\begin{array}{l}\text { Conell and } \\
\text { Lewitzka } \\
(2018)\end{array}$ & II & Case-control & 30 elderly & Analyze the assessment & - & $\begin{array}{l}\text { Psychotherapy at the patient's } \\
\text { home seems to be a new approach } \\
\text { to accommodate that individual's } \\
\text { circumstances and make effective } \\
\text { therapy possible }\end{array}$ \\
\hline 6 & $\begin{array}{l}\text { Cao et al. } \\
(2016)\end{array}$ & II & Cohort & $\begin{array}{l}1168 \text { older } \\
\text { adults }>60\end{array}$ & Evaluate utility score & $\begin{array}{l}\text { Measurement and evaluating } \\
\text { of health-promoting and } \\
\text { health-protecting behavior } \\
\text { intervention }\end{array}$ & $\begin{array}{l}\text { Those with depression were older, } \\
\text { less educated, had lower monthly } \\
\text { income, and were more likely to } \\
\text { report insomnia. }\end{array}$ \\
\hline 7 & $\begin{array}{l}\text { Dao et al. } \\
(2018)\end{array}$ & III & $\begin{array}{l}\text { Quasi with a control } \\
\text { group }\end{array}$ & 299 elderly & $\begin{array}{l}\text { Analyze the association between } \\
\text { depression and the factors associated }\end{array}$ & Self-reported depression & $\begin{array}{l}\text { Age and number of medicine } \\
\text { intake are positively correlated with } \\
\text { depression }\end{array}$ \\
\hline 8 & $\begin{array}{l}\text { Kolovos } \\
\text { et al. (2017) }\end{array}$ & 1 & RCT & 1629 elderly & $\begin{array}{l}\text { Evaluate whether utility scores are } \\
\text { different for various health states } \\
\text { related to depression severity }\end{array}$ & Average utility score & $\begin{array}{l}\text { Individuals with less severe } \\
\text { depressive symptoms had on } \\
\text { average statistically significant } \\
\text { higher utility scores than individuals } \\
\text { suffering from more severe } \\
\text { depressive symptomatology }\end{array}$ \\
\hline 9 & $\begin{array}{l}\text { Schwab } \\
\text { et al. (2015) }\end{array}$ & II & Case-control & 75 elderly & $\begin{array}{l}\text { Evaluate the variables associated } \\
\text { with HRQOL and HADS (Hospital } \\
\text { Anxiety-Depression Scale) }\end{array}$ & A score of quality life domains & $\begin{array}{l}\text { Quality of life and general health, } \\
\text { physical health, psychological health, } \\
\text { and environment associated with } \\
\text { HADS scores }\end{array}$ \\
\hline 10 & $\begin{array}{l}\text { llievová et al. } \\
\text { (2016) }\end{array}$ & III & $\begin{array}{l}\text { One group } \\
\text { before-after }\end{array}$ & 38 elderly & $\begin{array}{l}\text { Analyze the change of quality of life } \\
\text { and level of depression }\end{array}$ & GDS score & $\begin{array}{l}\text { Obtaining information on depression } \\
\text { and the quality of life of the elderly } \\
\text { in nursing home settings should } \\
\text { be introduced as a standard part } \\
\text { of nursing activities to improve the } \\
\text { quality of customer care in nursing } \\
\text { homes }\end{array}$ \\
\hline 11 & $\begin{array}{l}\text { Galeoto et al. } \\
(2018)\end{array}$ & II & Case-control & 119 elderly & Evaluate psychometric properties & Scale cutoff GDS & $\begin{array}{l}\text { GDS proved to be a reliable and } \\
\text { valid questionnaire for the evaluation } \\
\text { of depression. In the present study, } \\
\text { GDS showed good psychometric } \\
\text { properties }\end{array}$ \\
\hline 12 & $\begin{array}{l}\text { Stahl et al. } \\
(2017)\end{array}$ & 1 & RCT & 60 years older & $\begin{array}{l}\text { Describe the pros and cons of } \\
\text { incorporating spousal dyads into } \\
\text { depression prevention research }\end{array}$ & Depressive symptom & $\begin{array}{l}\text { A wife with mild cognitive } \\
\text { impairment could be trained as a } \\
\text { problem-solving therapy coach to } \\
\text { help her husband learn and use } \\
\text { problem-solving skills. Neither the } \\
\text { husband nor wife experienced an } \\
\text { incident episode of major depression } \\
\text { throughout the study }\end{array}$ \\
\hline 13 & $\begin{array}{l}\text { Areán et al. } \\
(2015)\end{array}$ & 1 & $\begin{array}{l}\text { RCT with parallel } \\
\text { design }\end{array}$ & $\begin{array}{l}271 \text { were screened, } \\
171 \text { were } \\
\text { randomized, } 60 \\
\text { years }\end{array}$ & $\begin{array}{l}\text { Problem-solving therapy - clinical case } \\
\text { management (CM-PST) and only CM }\end{array}$ & $\begin{array}{l}\text { WHO disability assessment } \\
\text { scale (WHO DAS) }\end{array}$ & $\begin{array}{l}\text { Both interventions resulted in } \\
\text { improved functioning by } 12 \text { weeks. } \\
\text { Change in disability was not affected } \\
\text { by baseline depression severity, } \\
\text { cognitive function, or number of } \\
\text { unmet social service needs }\end{array}$ \\
\hline 14 & $\begin{array}{l}\text { Stahl et al. } \\
(2017)\end{array}$ & 1 & RCT & Adults 60 and older & Problem-solving therapy & $\begin{array}{l}\text { Level of participation in } \\
\text { problem-solving activities }\end{array}$ & $\begin{array}{l}\text { Gait speed, a measure of } \\
\text { physical and cognitive health, } \\
\text { was significantly associated with } \\
\text { engagement in PST. Participants } \\
\text { who walked faster were more likely } \\
\text { to engage with PST compared to a } \\
\text { participant who walked more slowly }\end{array}$ \\
\hline 15 & $\begin{array}{l}\text { da Costa } \\
\text { Dias et al. } \\
\text { (2019) }\end{array}$ & 1 & RCT & 639 aged 75 years & Evaluate the prevalence rates & WHOQOL-OLD scale & $\begin{array}{l}\text { The depressed subject had poorer } \\
\text { measures of quality of life. Logistic } \\
\text { regression analyses showed that } \\
\text { depression was independently } \\
\text { associated with a history of falls/ } \\
\text { fracture, a diagnosis of cognitive } \\
\text { impairment -no dementia, the } \\
\text { number of regular drugs used, lack } \\
\text { of reading habit, and inversely, to } \\
\text { systolic blood pressure }\end{array}$ \\
\hline
\end{tabular}


Table 2: (Continued)

\begin{tabular}{|c|c|c|c|c|c|c|c|}
\hline No. & Author, Year & $\begin{array}{l}\text { Level of } \\
\text { evidence }\end{array}$ & Study design & Sample size & Intervention & Outcome measures & Results \\
\hline 16 & $\begin{array}{l}\text { Lara et al. } \\
(2016)\end{array}$ & II & Cohort & 1958 aged 65 years & $\begin{array}{l}\text { Investigating depression association } \\
\text { with mortality }\end{array}$ & $\begin{array}{l}\text { Depressive symptomatology } \\
\text { and mortality }\end{array}$ & $\begin{array}{l}\text { Depressive symptomatology } \\
\text { constitutes an independent risk } \\
\text { factor that leads to excess mortality } \\
\text { in the general population }\end{array}$ \\
\hline 17 & $\begin{array}{l}\text { Chen et al. } \\
(2016)\end{array}$ & I & RCT & $\begin{array}{l}634 \text { participants } \\
\text { aged }>60 \text { years }\end{array}$ & $\begin{array}{l}\text { Screening major depression disorder } \\
\text { in primary care elderly patient }\end{array}$ & Scale of depression & $\begin{array}{l}\text { PHQ-9, PHQ-2, and PHQ-1 are valid } \\
\text { and reliable to screen depression } \\
\text { in primary care elderly patients and } \\
\text { could be proper alternatives to the } \\
\text { GDS-15 version }\end{array}$ \\
\hline 18 & $\begin{array}{l}\text { Siverová and } \\
\text { Bužgová } \\
\text { (2018) }\end{array}$ & III & $\begin{array}{l}\text { Quasi-experimental } \\
\text { study }\end{array}$ & $\begin{array}{l}59 \text { intervention } \\
\text { group, } 57 \text { control } \\
\text { group }\end{array}$ & Reminiscence therapy & $\begin{array}{l}\text { The scale of quality of life, } \\
\text { depressive symptoms, } \\
\text { cognition, and attitudes toward } \\
\text { aging }\end{array}$ & $\begin{array}{l}\text { Reminiscence therapy can positively } \\
\text { affect selected aspects of quality of } \\
\text { life, attitudes toward old age, and } \\
\text { symptoms of depression in the elderly } \\
\text { in long-term health-care facilities }\end{array}$ \\
\hline 19 & $\begin{array}{l}\text { Clignet et al. } \\
\text { (2017) }\end{array}$ & 1 & RCT & 26 old age & Systematic Activation Method & $\begin{array}{l}\text { Level of depression and } \\
\text { cognitive functioning }\end{array}$ & $\begin{array}{l}\text { Facilitators and barriers relating to } \\
\text { patient and nurse characteristics, as } \\
\text { well as to contextual factors, from } \\
\text { the perspective of mental-health } \\
\text { nurses. The nature of depression } \\
\text { and the quality of life of the } \\
\text { therapeutic relationship was a } \\
\text { major aspect that affected the } \\
\text { implementation of SAM }\end{array}$ \\
\hline 20 & $\begin{array}{l}\text { Laudisio } \\
\text { et al. (2018) }\end{array}$ & III & $\begin{array}{l}\text { One group } \\
\text { before-after }\end{array}$ & $\begin{array}{l}344 \text { aged } 75 \text { years } \\
\text { and above }\end{array}$ & $\begin{array}{l}\text { Search for GDS cutoff level that might } \\
\text { identify a decrease in perceived QOL }\end{array}$ & Scale of GDS & $\begin{array}{l}\text { The depressive symptom is } \\
\text { associated with reduced QOL; GDS } \\
\text { scores above } 9 / 30 \text { or } 5 / 15 \text { best } \\
\text { predict poor perceived health-related } \\
\text { QOL. These cutoff scores could, } \\
\text { therefore, identify subjects in whom } \\
\text { treatment is more likely to improve } \\
\text { QOL and to yield a favorable } \\
\text { cost-effectiveness ratio }\end{array}$ \\
\hline 21 & $\begin{array}{l}\text { Alcañiz and } \\
\text { Solé-Auró } \\
\text { (2018) }\end{array}$ & II & Cohort & $\begin{array}{l}2264 \text { aged } 80 \text { years } \\
\text { and above }\end{array}$ & $\begin{array}{l}\text { Identify those attributes that might be } \\
\text { modified during younger stages of the } \\
\text { life course }\end{array}$ & HRQL scale & $\begin{array}{l}\text { Encouraging the young to stay } \\
\text { in education, as well as to adopt } \\
\text { healthier lifestyles across the } \\
\text { lifespan, might ensure better HRQL } \\
\text { when individuals reach old age }\end{array}$ \\
\hline $22^{\star}$ & $\begin{array}{l}\text { Emmerink } \\
\text { and Roeg } \\
(2016)\end{array}$ & III & Quasi-exp. & 523 old age & Known on ICBC clients SQOL & SQOL scale & $\begin{array}{l}\text { Symptomatology and social problem } \\
\text { negatively influenced the SQOL, } \\
\text { while having a partner, a good } \\
\text { friend, and an overall lower problem } \\
\text { severity positively influenced SQOL }\end{array}$ \\
\hline 23 & $\begin{array}{l}\text { Ghimire et al. } \\
(2018)\end{array}$ & III & Quasi-exp. & 289 aged $>60$ years & $\begin{array}{l}\text { Evaluate nutritional health and mental } \\
\text { well-being }\end{array}$ & $\begin{array}{l}\text { Nutritional status, depression, } \\
\text { life satisfaction }\end{array}$ & $\begin{array}{l}\text { Life satisfaction was positively } \\
\text { associated with being married, high } \\
\text { family income, involvement in active } \\
\text { earning, and high nutritional score }\end{array}$ \\
\hline 24 & $\begin{array}{l}\text { Hajek et al. } \\
(2017)\end{array}$ & II & Cohort & 2364 old age & $\begin{array}{l}\text { Examine the impact of social } \\
\text { engagement on } \mathrm{HRQOL} \text { and } \\
\text { depressive symptom }\end{array}$ & HRQOL and GDS scale & $\begin{array}{l}\text { Encouraging the individuals to } \\
\text { start, maintain and expand social } \\
\text { engagement in late life might help to } \\
\text { maintain and improve HRQOL and } \\
\text { decrease depressive symptoms }\end{array}$ \\
\hline 25 & $\begin{array}{l}\text { Wang et al. } \\
\text { (2017) }\end{array}$ & II & Cohort & $\begin{array}{l}839 \text { aged } 60 \text { or } \\
\text { above }\end{array}$ & $\begin{array}{l}\text { Comparing loneliness, depressive } \\
\text { symptom between empty-nest and } \\
\text { not-empty-nest older adults in rural }\end{array}$ & Depressive symptom & $\begin{array}{l}\text { Path analysis showed that } \\
\text { loneliness mediated the relationship } \\
\text { between empty-nest syndrome and } \\
\text { depressive symptoms and major } \\
\text { depressive episodes }\end{array}$ \\
\hline
\end{tabular}

will be excited and optimistic. The task at this time is to accept the elderly and prepared for the loss, in other words, the achievement of self-integrity. Nevertheless, on the other hand, previous negative experiences influence failure, so they are not excited and are not ready to face old age and loss, in other words, despair.

Life satisfaction that affects happiness consists of two subdimensions, namely, personal life satisfaction and social life satisfaction which includes 10 domains related to essential aspects of human life, namely, education, work, household income, physical and mental health (aloneness), family harmony, availability of free time, social relations, environmental conditions, and security conditions, as well as the condition of the house and home facilities. Considering the use of 10 indicators as a constituent of the dimensions of life satisfaction that one of these indicators, namely physical and mental health, is a very important indicator for the elderly to be able to carry out daily life both in terms of work and social relations between humans. Positive emotions are felt by the elderly, who can help to make sense of life. Positive emotions are categorized into three categories, namely, positive emotions in the past, in the future positive emotions, and positive emotions at this time.

History of chronic disease and self-care inability can be predisposing factors when there are no adaptive coping. Diseases experienced by the elderly are part of a natural process in the elderly that occur continuously and continuously but need to be anticipated so that there are no negative impacts. Changes in the anatomy, physiology, and biochemistry of tissues or organs ultimately affect the 
Table 3: Risk of bias

\begin{tabular}{|c|c|c|c|c|c|c|c|c|}
\hline \multirow[t]{2}{*}{ No. } & \multirow[t]{2}{*}{ Citation } & \multicolumn{2}{|l|}{ Selection bias } & \multirow{2}{*}{$\begin{array}{l}\text { Performance bias } \\
\text { Blinding of participants } \\
\text { and personnel }\end{array}$} & \multicolumn{2}{|l|}{ Detection bias } & \multirow{2}{*}{$\begin{array}{l}\text { Attrition bias } \\
\text { Incomplete } \\
\text { outcome data }\end{array}$} & \multirow{2}{*}{$\begin{array}{l}\text { Reporting } \\
\text { bias } \\
\text { Selective } \\
\text { reporting }\end{array}$} \\
\hline & & $\begin{array}{l}\text { Random sequence } \\
\text { generation }\end{array}$ & $\begin{array}{l}\text { Allocation } \\
\text { concealment }\end{array}$ & & $\begin{array}{l}\text { Binding of outcome } \\
\text { assessment: } \\
\text { Self-reported } \\
\text { outcomes }\end{array}$ & $\begin{array}{l}\text { Blinding of outcomes } \\
\text { assessment: Objective outcomes }\end{array}$ & & \\
\hline 1 & Lin et al. (2014) & + & + & + & + & + & $?$ & $?$ \\
\hline 2 & Holland et al. (2015) & - & - & + & + & + & + & + \\
\hline 3 & Ho et al. (2017) & + & + & + & + & + & + & - \\
\hline 4 & Feng et al. (2014) & + & + & + & + & + & + & - \\
\hline 5 & Conell and Lewitzka (2018) & + & + & + & + & + & + & - \\
\hline 6 & Cao et al. (2016) & + & + & + & + & + & + & - \\
\hline 7 & Dao et al. (2018) & + & + & + & + & + & + & - \\
\hline 8 & Kolovos et al. (2017) & + & + & + & + & + & + & - \\
\hline 9 & Schwab et al. (2015) & + & + & + & + & + & + & - \\
\hline 10 & llievová et al. (2016) & + & + & + & + & + & + & - \\
\hline 11 & Galeoto et al. (2018) & + & + & + & + & + & + & - \\
\hline 12 & Stahl et al. (2017) & + & + & + & + & + & + & - \\
\hline 13 & Areán et al. (2015) & + & + & + & + & + & + & - \\
\hline 14 & Stahl et al. (2017) & + & + & + & + & + & + & - \\
\hline 15 & da Costa Dias et al. (2019) & + & + & + & + & + & + & - \\
\hline 16 & Lara et al. (2016) & + & + & ? & + & + & + & + \\
\hline 17 & Chen et al. (2016) & + & + & ? & + & + & + & + \\
\hline 18 & Siverová and Bužgová (2018) & + & + & ? & + & + & + & + \\
\hline 19 & Clignet et al. (2017) & + & + & - & + & + & + & + \\
\hline 20 & Laudisio et al. (2018) & + & + & - & + & + & + & + \\
\hline 21 & Alcañiz and Solé-Auró (2018) & + & + & - & + & + & + & + \\
\hline 22 & Emmerink and Roeg (2016) & + & + & + & + & + & + & $?$ \\
\hline 23 & Ghimire et al. (2018) & $?$ & + & + & + & + & - & + \\
\hline 24 & Hajek et al. (2017) & $?$ & - & + & + & + & + & + \\
\hline 25 & Wang et al. (2017) & - & ? & + & + & + & + & + \\
\hline
\end{tabular}

state, function, and ability of the elderly as a whole. Cell changes in the organ systems of the elderly will affect the elderly to have the ability to function adequately and survive from disease and other stressors. Of course, this affects the process of the brain processing all life events in the elderly that impact mental health status and happiness. The brain and immune systems are constantly signaling each other, often in the same way that can explain how the state of mind of the elderly affects mental health. The immune system's job is to drive foreign pathogens away from the body and recognize and destroy them by breaking through the barrier. Aging is the gradual loss of the ability of tissues to repair themselves or maintain typical structure and function. The purpose of human life is to grow old and stay healthy (healthy aging). Healthy aging means growing old in a healthy state without being accompanied by pathological processes.

The most common strategy for dealing with the problem made by respondents aged $60^{\text {th }}-80^{\text {th }}$ year of the most stressful events in religion and religious activities. So that the stimulus for the spiritual aspect of the elderly is more dominant in the form of religiosity, the elderly need to be given freedom and facilities to participate in activities related to spirituality and religiosity. Spiritual needs can provide inner peace. So that religiosity or religious appreciation of significant influence on the health state of physical and mental health, where spiritual and religious improvement will provide benefits for the elderly such as being calmer in living life, being able to adjust to the elderly phase and being more prepared to undergo the next phase of life. The elderly nonreligious mortality rate is 2 times greater than a religious person. The elderly religious healing of the disease is sooner than non-religious. The elderly religious is more robust and resilient to face stress than nonreligious, so the mental-emotional disorder is much smaller. The elderly are religious steadfast and calm in the face of the last moment (death) than the non-religious.

\section{Discussion}

Most patients did not know that they were suffering from depression [20]. The lack of awareness might have a considerable impact on the patient's QoL, as these patients might continue to suffer without any medical attention, and nursing care only delivers at the advanced stage. We found that the participants recruited from the rural area had a significantly higher prevalence of geriatric depression than their urban counterparts. Aged persons living in rural areas were likely to have poorer access to health-care services [25]. The environment might have culminated in increased suffering from chronic diseases resulting in an increased likelihood of developing depression. Being poorly educated, most of our study subjects had a higher likelihood of having low awareness and poor QoL.

Religious belief is one of the highest correlated with depression. Government regulation on religious practices and restrictions on religious worship might be potential contributors [19]. Reverse causation could well explain some of the correlations as mentioned earlier and results in poor self-esteem and depression that had influenced them to become more religious.

Religious belief [17], satisfaction [18] regarding the happiness and QoL, suffering from more chronic 
disease [21], experiencing an adverse event [16], and lack of ability to take self-care were associated with having geriatric depression [8]. Factors affecting depressive symptoms are female gender, duration of hospital stay, and rehabilitation [9]. The depressed subject had poorer measures of QoL. Logistic regression analyses showed that depression was independently associated with a history of falls/fracture [27], a diagnosis of cognitive impairment - no dementia [26], the number of regular drug use, lack of reading habit, and inversely, to systolic blood pressure [10]. Those with more education showed improvement in their ability to regain positive values, worldviews, and purpose in life.

There are differences in depression levels in the elderly who live in nursing homes compared to the elderly who live with family at home. Family support and social support significantly affect the level of depression experienced by the elderly. Psychotherapy at the patient's home seems to be a new approach to accommodate that individual's circumstances and make effective therapy possible [11]. A significant number of the elderly cannot join psychotherapy simply because of their restricted mobility. Community-based care, especially at home, applies to where the therapy takes place, its duration, frequency, and the total number of sessions.

Besides these, the inability to take self-care in daily life positively correlated with depression. As a potential risk factor for depression, this disability could increase physical and social requirements among the elderly [25]. And then, participants who experienced three or more negative events in the past 2 years had a higher likelihood of developing depression. Adverse events in daily life probably triggered the development of depression among them by inducing negative emotion, stress, loneliness, and hopelessness. The research hypothesis is answering in the discussion. Emphasis on similarities, differences, or the uniqueness of the findings obtained. In addition, it needs to discuss the reason for the findings. The implications of this review are to strengthen recommendations for intervention in depressed elderly so that they can consider the essential factors that make the elderly achieve selfintegrity with feelings of happiness.

\section{Conclusion}

The strength of our synthesis of evidence is that it identifies the essential factor influencing the QoL in depressed elderly. A clear understanding of the predisposing factors is critical to understand better and effectively prevent the elderly's experiences with depression. Understanding the elderly perception about the QoL and how it contributes to the lives of the elderly with depression is fundamental for providing effective nursing interventions in geriatric settings. Screening for early depression, providing psychosocial developmental task stimulation, and empowering material assets may minimize the depression predisposing factors. In addition, screening for early depression, joining social programming, and participating in physical activities may improve the mental health life, happiness, and QoL of the elderly.

\section{Acknowledgments}

The author would like to thank the Directorate of Research and Development Universitas Indonesia for funding the research activities and publication and the Center for Family and Aging Studies Universitas Respati Indonesia for fully supporting material in research.

\section{References}

1. Tri BWR, Dinni A, Guritno E. Service Delivery for Older Persons by Young Generation in Indonesia. Jakarta: Indonesia Ministry of Health; 2017.

2. World Health Organization. Depression and common mental health disorders. Global Health estimation. Geneva. 2017. WHO. [Last accessed on 08 Sep 2020].

3. Dao AT, Nguyen VT, Nguyen HV, Nguyen LT. Factors associated with depression among the elderly living in Urban Vietnam. Biomed Res Int. 2018;2018:2370284. https://doi. org/10.1155/2018/2370284

PMid:30596085

4. Kemenkes RI. Hasil Riset Kesehatan Dasar Tahun 2018. Vol. 53. Jakarta, Indonesia: Kementerian Kesehatan RI; 2018. p. 1689-99.

5. Moher D, Liberati A, Tetzlaff J, Altman DG, PRISMA Group. Preferred reporting items for systematic reviews and meta-analyses: The PRISMA statement. PLoS Med. 2009;6(7):e1000097. https://doi.org/10.1371/journal. pmed.1000097

PMid: 19621072

6. Cao, W., Guo, C., Ping, W., Tan, Z., Guo, Y., \& Zheng, J. A Community-Based Study of Quality of Life and Depression among Older Adults. International Journal Of Environmental Research And Public Health. 2016. 13(7). doi:10.3390/ ijerph13070693.

7. Galeoto G, Sansoni J, Scuccimarri M, Bruni V, De Santis R, Colucci M, et al. A Psychometric properties evaluation of the Italian version of the geriatric depression scale. Depress Res Treat. 2018;2018:1797536. https://doi.org/10.1155/2018/1797536 PMid:29686898

8. Feng L, Li P, Lu C, Tang W, Mahapatra T, Wang $\mathrm{Y}$, et al. Burden and correlates of geriatric depression in the Uyghur elderly population, observation from Xinjiang, China. PLoS One. 2014;9(12):e114139. https://doi.org/10.1371/journal. pone. 0114139 .

PMid:25437860 
9. Lin JH, Huang MW, Wang DW, Chen YM, Lin CS, Tang YJ, et al. Late-life depression and quality of life in a geriatric evaluation and management unit: An exploratory study. BMC Geriatr. 2014;14:77. https://doi.org/10.1186/1471-2318-14-77 PMid:24941865

10. Ilievová, L'., Žitný, P., \& Jakobejova, J. (2016). The association between the quality of life and depression of elderly in a nursing home institutional setting. Journal of Health Sciences, 6(3), 162167. doi:http://dx.doi.org/10.17532/jhsci.2016.364.

11. Conell J, Lewitzka U. Adapted psychotherapy for suicidal geriatric patients with depression. BMC Psychiatry. 2018;18(1):203. https://doi.org/10.1186/s12888-018-1775-y PMid:29914407

12. Laudisio A, Antonelli Incalzi R, Gemma A, Marzetti E, Pozzi G, Padua L, et al. Definition of a Geriatric Depression Scale cutoff based upon quality of life: A population-based study. Int J Geriatr Psychiatry. 2018;33(1):e58-64. https://doi.org/10.1002/gps.4715 PMid:28370551

13. Holland JM, Chong G, Currier JM, O'Hara R, Gallagher-Thompson D. Does cognitive-behavioural therapy promote meaning making? A preliminary test in the context of geriatric depression. Psychol Psychother. 2015;88(1):120-4. https://doi.org/10.1111/papt.12030

PMid:24839175

14. Stahl ST, Rodakowski J, Gildengers AG, Reynolds CF, Morse JQ, Rico K, Butters MA. Treatment Considerations for Depression Research in Older Married Couples: A Dyadic Case Study. The American Journal of Geriatric Psychiatry. 2017. 25(4), 388-395. doi:https://doi.org/10.1016/j.jagp.2016.12.013

15. Da Costa Dias FI, Teixeira AL, Guimarães HC, Santos AP, Ritter $\mathrm{SR}$, Machado JC, et al. Prevalence of late-life depression and its correlates in a community-dwelling low-educated population aged 75+ years: The Pietà study. J Affect Disord. 2019;242:1739. https://doi.org/10.1016/j.jad.2018.08.012 PMid:30189354

16. Wang G, Hu M, Xiao SY, Zhou L. Loneliness and depression among rural empty-nest elderly adults in Liuyang, China: A cross-sectional study. BMJ Open. 2017;7(10):e016091. https://doi.org/10.1136/bmjopen-2017-016091 PMid:28988166

17. Wongpakaran $\mathrm{N}$, Wongpakaran $\mathrm{T}$, Lerttrakarnnon $\mathrm{P}$, Jiraniramai S, Sirirak T, Assanangkornchai S, et al. Prevalence, clinical and psychosocial variables of depression, anxiety and suicidality in geriatric tertiary care settings. Asian J Psychiatr. 2019;41:38-44. https://doi.org/10.1016/j.ajp.2018.10.007 PMid:30348596

18. Yaka E, Keskinoglu P, Ucku R, Yener GG, Tunca Z. Prevalence and risk factors of depression among community dwelling elderly. Arch Gerontol Geriatr. 2014;59(1):150-4. https://doi. org/10.1016/j.archger.2014.03.014

PMid:24767692

19. Zhang $C$, Xue Y, Zhao H, Zheng X, Zhu R, Du Y, et al. Prevalence and related influencing factors of depressive symptoms among empty-nest elderly in Shanxi, China. J Affect Disord. 2019;245:750-6. https://doi.org/10.1016/j.jad.2018.11.045 PMid:30448759

20. Stahl ST, Rodakowski J, Gildengers AG, Reynolds CF $3^{\text {rd }}$, Morse JQ, Rico K, et al. Treatment considerations for depression research in older married couples: A dyadic case study. Am J Geriatr Psychiatry. 2017;25(4):388-95. https://doi.org/10.1016/j. jagp.2016.12.013

PMid:28237826

21. Tanaka T, Tanaka K, Suyama K, Honda S, Senjyu H, Kozu R. A comparison of objective physical activity, muscle strength, and depression among community-dwelling older women living in sloped versus non-sloped environments. J Nutr Health Aging. 2016;20(5):520-4. https://doi.org/10.1007/s12603-015-0602-0 PMid:27102790

22. Emmerink PMJ, Roeg DPK. Predictors of quality of life of people receiving intensive community-based care. Quality of Life Research. 2016. 25(2), 457-464. doi:10.1007/ s11136-015-1093-5.

23. Ghimire S, Baral BK, Karmacharya I, Callahan K, Mishra SR. Life satisfaction among elderly patients in Nepal: Associations with nutritional and mental well-being. Health and Quality of Life Outcomes. 2018 .16 (1). doi:10.1186/s12955-018-0947-2

24. Hajek A, Brettschneider C, Mallon T, Ernst A, Mamone S, Wiese B, Zimmermann T. The impact of social engagement on health-related quality of life and depressive symptoms in old age - evidence from a multicenter prospective cohort study in Germany. Health and Quality of Life Outcomes. 2017. 15(1). doi:10.1186/s12955-017-0715-8

25. Christie HL, Martin JL, Connor J, Tange HJ, Verhey FR, de Vugt ME, et al. eHealth interventions to support caregivers of people with dementia may be proven effective, but are they implementation-ready? Internet Interv. 2019;18:100260. https:// doi.org/10.1016/j.invent.2019.100260

PMid:31890613

26. Derdaele E, Toussaint L, Thauvoye E, Dezutter J. Forgiveness and late life functioning: The mediating role of finding egointegrity. Aging Ment Health. 2019;23(2):238-45. https://doi.org/ 10.1080/13607863.2017.1399346 PMid:29115858

27. Myoungjin K, Sun-Ae K, Kawoun S. Systematic review on the relationship between depressive symptoms and activities of daily living in cognitively intact older adults. Korean J Adult Nurs. 2019;31(1):1-13. https://doi.org/10.7475/kjan.2019.31.1.1 